\title{
Ativismo judicial e o problema metodológico da discricionariedade judicial para a formação de uma política criminal
}

\section{Judicial activism and the methodological problem of judicial discretionary for the formation of a criminal policy}

\section{Resumo}

Este artigo pretende demonstrar as raízes do Ativismo Judicial brasileiro, como fenômeno proporcionado pela deturpada compreensão da aplicação dos princípios jusfundamentais, colocando em destaque, por um lado, sua incongruência com a ideia de Discricionariedade Judicial, por outro, a produção de uma irreal política criminal.

Palavras-chave: Ativismo Judicial. Discricionariedade. Política Criminal.

\begin{abstract}
This paper aims to demonstrate the roots of the Brazilian Judicial Activism, as a phenomenon provided by distorted understanding of the application of the constitutional principles, placing emphasis firstly, on its incongruity idea of Judicial Discretionary, secondly, the production of an unrealistic criminal policy.
\end{abstract}

Keywords: Judicial activism. Discretionary. Criminal Policy.

\footnotetext{
${ }^{1}$ Possui graduação em Direito pela Universidade Federal de Santa Catarina (1988); mestrado em Direito pela Universidade de Coimbra; doutorado em direito pela UNIVALI; doutorado em direito pela Università Degli Studi di Perugia. É Promotor de Justiça do Ministério Público de Santa Catarina. Membro do Conselho Editorial da Revista Jurídica do Ministério Público - Santa Catarina; professor da UNIVALI. Professor convidado da Escola Superior do Ministério Público do Estado de Santa Catarina. Tem experiência na área de Direito, com ênfase em Direito Penal, atuando principalmente nos seguintes temas: política criminal, direito penal, constituição, criminologia e crime. Tem investigado sobre os problemas do ensino jurídico brasileiro. Fez investigações sobre Direitos Humanos e política jurídica, eixo central de sua tese de doutoramento.
} 


\section{Introdução}

A última onda (vague) de constitucionalização moderna, a quarta segundo Hauriou, terá ocorrido após a Segunda Guerra Mundial, sendo consequente do movimento de descolonização ${ }^{2}$. Depois disso, parece haver um declínio do constitucionalismo, que coincide, por um lado, com o processo de transformações econômicas do século XX que dão os contornos da Globalização; por outro, quem sabe como fator amalgamado a este, o fenômeno associa-se à crise do Estado que, agigantado em suas funções de satisfação do bem-estar social, já não atua somente por meio do poder político, mas cede espaço às intervenções de políticas não governamentais. Sob esse aspecto, o Estado será um ente político bem mais complexo do que definiu Kelsen ao preconizar a teoria da interação, segundo a qual o Estado seria resultante da unidade social e da unidade jurídica ${ }^{3}$ : a abertura (circunstancial e necessária) aos espaços transnacionais de política, Direito e economia, enfraquecem algumas das bases estabelecidas na Constituição, como a ideia de soberania, e, claro, as próprias instituições, como o legislativo.

Diante de um legislativo cooptado pela circunstância política que, aliás, atinge inclusive a ideia de democracia em razão de não se verem quadros ideológicos e programáticos bem definidos entre os partidos políticos, que desemboca na apatia, senão no imobilismo, os Juízes nacionais têm engrossado as fileiras contramajoritárias, atuando em áreas que, a rigor, competiriam ao Congresso, mas sob os pretextos da emergência e da discricionariedade que é ínsita à judicatura. Para preencherem os espaços vazios deixados nas Leis ou pela falta delas, os Juízes servem-se do instrumentário principiológico abrigado na Constituição não apenas para decretarem a inconstitucionalidade de normas infraconstitucionais, mas, também, para criarem normas positivadas em suas decisões, um Direito ex novo e paradigmático para novas decisões, as quais avançam sobre a política criminal, cada vez mais localizável nos tribunais do no Congresso.

Pretendendo dar maior força argumentativa à sua política criminal, os tribunais e penalistas, muitos do quais também pertencentes ao mundo da práxis jurídi-
HAURIOU, André. Droit Constitutionnel et institutions poliques. 3. ed. Paris: Éditions Montchrestian, 1968. p. 79. KELSEN, Hans. Teoria geral do direito e do Estado. Tradução de Luís Carlos Borges. São Paulo: M. Fontes, 2005. p. 265. co-jurisdicional, denunciam o Direito Penal simbólico a existência de alarmismo da mídia quanto à criminalidade $^{5}$ e um ambiente de democracia material que não admite medidas restritivas de liberdade (a menos que de forma excepcionalíssima), mas, ao invés, propicia uma viragem liberal rumo às garantias individuais da liberda$\mathrm{de}^{6}$, quando não uma mais agressiva política descriminalização ${ }^{7}$. Isso tem algum cabimento se levarmos em conta a simplificação da política criminal levada a efeito pelo legislador (que atua sem o arrimo de uma bem fundamentada criminologia para criar soluções emergenciais), o sensacionalismo da imprensa (que vive de notícias e fatos capazes de aumentar o número de leitores e a audiência dos telespectadores) e as bases de nossa Constituição em princípios de cariz axiológico (que advêm de incontestáveis valores humanitários). Mas esta é apenas uma das perspectivas de se entender a complexa teia fenomênica (que ao fim e ao cabo desaguada num complexo sistema social ${ }^{8}$ ), a todas as luzes político-ideologicamente engajada.

Nosso intuito aqui não é estabelecer uma crítica contra o engajamento político-ideológico de Juízes e tribunais (até porque isso pressuporia nossa adesão a al-

No Brasil, o desembargador Alberto Silva Franco, amparado em Antonio García-Pablos, opõe-se ao recurso de Leis penais pelos legisladores, que pretendem mais produzir uma impressão tranquilizadora para o público, do que criar mecanismos efetivos de resolução do problema criminal. FRANCO, Alberto Silva. Do princípio da intervenção mínima ao princípio da máxima intervenção. Revista Portuguesa de Ciência Criminal, v. 2, p. 182-183, abr./jun. 1996. Também, SABBÁ GUIMARÃES, Isaac. Dogmática penal e poder punitivo. Novos rumos e redefinições. 2. ed. rev. e atual. Curitiba: Juruá, 2001. p. 60 e ss.

5 SOUZA, Marcelo Ferreira de. Segurança pública e prisão preventiva no Estado Democrático de Direito. Rio de Janeiro: Lumen Júris, 2008. 22, amparado no Juiz Alexandre Morais da Rosa, diminui o impacto da violência sobre as medidas de segurança pública, creditando-o ao alarde da mídia.

6 ROSA, Alexandre Morais da. Garantismo jurídico e controle de constitucionalidade material: aportes hermenêuticos. 2. ed. Rio de Janeiro: Lumen Juris. 2011. p. 5 e ss.

7 KARAM, Maria Lúcia. Drogas e redução de danos. Revista Brasileira de Ciências Criminais, São Paulo, n. 64, p. 128144, jan./fev. 2007. compara a punição do tráfico de drogas à "proibição da circulação de ideias", o que, a todas as luzes, não se compagina com um Estado democrático de direito, defendendo, por isso, sua descriminalização. $\mathrm{O}$ trabalho da Juíza carioca é analisado em SABBÁ GUIMARÃES, Isaac. Lei antidrogas comentada. 6. ed. rev. atual. e ampl. Curitiba: Juruá, 2013. nos comentários ao art. 33 da Lei, no tópico aspectos criminais.

$8 \quad$ Aliás, reconhecido por Alexandre de Morais da Rosa. 
guma ideologia), mas, antes, tentar descobrir os pontos de contato entre Ativismo Judicial e Discricionariedade, estabelecendo marcos epistemológicos para as duas categorias. Os pontos críticos (de desacerto metodológico) serão descobertos por meio da dialética entre Ativismo e o sistema jurídico vigente e a política criminal debuxada pela experiência jurídico-jurisdicional moderna.

A investigação, o tratamento dos dados e a elaboração do relato sob a forma de artigo, são realizados com base no método indutivo, e as técnicas utilizadas são a do referente, a de categorias e de conceitos operacionais. As categorias utilizadas terão seus conceitos operacionais descritos ao longo do trabalho.

\section{Aspectos epistemológicos acerca da discri- cionariedade judicial}

A antiga compreensão do Juiz como la bouche de la Loi, própria do sistema jurídico preconizado pela École de l'exégèse, quando o positivismo reduzia a concretização do Direito à interpretação da Lei, levada a efeito pela subsunção do fato à regra legal - e, portanto, a realização do Direito processava-se por meio de silogismos —, não será suficiente para as concreções normativas - as que se verificam nas decisões judiciais. Em primeiro lugar, porque a expressão do Direito por meio de regras legais sujeita-se à polissemia, e dificilmente o jurista encontrará exatidão, um sentido preciso para a mítica e propalada vontade da Lei. Não é demais lembrarmos, a propósito disso, que os vocábulos substantivam-se de forma variegada consoante os jogos de linguagem em que se encaixam; além do que, adquirem novas conotações a cada arrasto histórico, que ou os desgasta, ou enriquece-os pela agregação de outros significados ${ }^{9}$. Em segundo lugar, temos de considerar

Em SABBÁ GUIMARÃES, Isaac. Compreensão da vontade do Direito: um problema da filosofia da linguagem. MPMG Jurídico, v. 20, p. 16-18, 2010. Lê-se: “o agrupamento [das palavras] em razão da semelhança de função que desempenham na linguagem (formando o que Wittgenstein chamou de semelhanças de família), se associam a novos sentidos (se falarmos de boa-fé, na comunicação jurídica, o termo variará de extensão semântica consoante o jogo de linguagem em causa; e a boa-fé será avaliada, v.g., segundo a maior ou menor capacidade de comportamento ético da pessoa sub examen numa ação); de forma que os jogos de linguagem não se sujeitem a uma fixidez de parâmetros, mas, ao invés, vão aderindo a outras circunstâncias da comunicação humana (inclusive sociolinguísticas)." V., também, WITTGENSTEIN, Ludwig. Tratado lógico-filosó- que as Leis são fragmentárias, não podendo abranger a totalidade de situações com importância jurídica determinadas pelos fenômenos humanos. Disso já se haviam dado conta os legisladores franceses que redigiram o Code Napoleon (1804), em cujo art. $4^{\circ}$ reconheceram a possibilidade de silêncio, obscuridade ou insuficiência da Lei, o que requererá do Juiz outros expedientes para dizer o Direito, tarefa da qual não se pode eximir ${ }^{10}$. Isso quer-nos indicar que o Juiz, ao positivar uma norma jurídica, concreta e para um caso individuado - elaborando uma norma casuística, portanto - , opera hermeneuticamente, procurando o melhor sentido para as normas normadas pelo legislador, de caráter genérico e abstrato. Ou, segundo uma visão da metodologia jurídica, os Juízes transpõem as regras abstratas e genéricas positivadas em Lei, positivando normas para casos concretos e individuados em suas sentenças.

A fixação da premissa de que o Juiz não encontra soluções prontas e acabadas na Lei, seja em razão de suas imperfeições linguísticas, seja por que o ordenamento jurídico é, tout court, fragmentário, leva-nos a admitir que o ofício judicante só será possível na medida em que aceitarmos uma figura de magistrado diversa do ser autômato, o que executa seu mister mecânica e burocraticamente. Por outras palavras, a interpretação das normas jurídicas e sua transposição do âmbito abstrato e genérico para o da concreção e individuação do Direito, exige que se estabeleça uma esfera de liberdade para a atuação do Juiz que, dispondo da prerrogativa-dever de decidibilidade, há de chegar ao resultado mais adequado, necessário e razoável para a questão problemática. Essa é a prerrogativa da Discricionariedade Judicial.

Mas isso não quer dizer que o Juiz, tal como um Deus ex machina, possa irromper no processo com uma decisão de todo em todo inusitada e original. A liberdade para interpretar e criar a norma positiva não equivale, pois, a um poder ilimitado. A atuação judicial e a bondade $^{11}$ das decisões devem ser aferidas, por um lado, in-

fico: Investigações filosóficas. Lisboa: Calouste Gulbenkian, 2002. (há boas edições brasileiras das Investigações filosóficas).

10 Art. 4. Le juge qui refusera de juger, sous pretexte du silence, de l'obscurité ou de l'insuffisance de la loi, pourrà être poursuivi comme coupable de déni de justice.

11 O termo é aqui empregue, em parte apoiado na acepção moral de Tomás de Aquino, é relacionado com a noção de justeza do ato. 
ternamente ao desenvolvimento decisório, de modo que se evidencie o cabimento da norma casuisticamente positivada dentro de limites legalmente estabelecidos; e, por outro, externamente, onde a decisão produz seus efeitos, devendo ela manifestar um bonum, a expressão daquilo que é jurídica e eticamente aceitável. Assim, nessa primeira aproximação à categoria, podemos dizer que Discricionariedade Judicial "es un cierto margen de libertad en la toma de decisiones." 12 Dessa forma, o Juiz que, v.g., na operação de dosagem de pena de um réu condenado verificar a concorrência dos requisitos descritos no art. 44 do Código Penal (pena privativa de liberdade atribuível ao fato não superior a quatro anos, correspondente a crime não cometido com violência ou grave ameaça; ou, se o crime for culposo; se a culpabilidade e circunstâncias pessoais indicarem a adequação da substituição da pena), substituirá a pena privativa de liberdade por uma ou mais restritivas de direitos; e sua escolha, em forma de norma positiva concreta e individualizada, recairá sobre aquelas descritas no art. 43, CP (prestação pecuniária, perda de bens e valores, prestação de serviço à comunidade ou a entidades públicas, interdição temporária de direitos, limitação de fim de semana).

A noção acima descrita, no entanto, contempla uma das formas de encarar-se a Discricionariedade Judicial, que se refere à possibilidade de escolha entre várias alternativas; todas elas possíveis e, em caso de aplicação, juridicamente válidas. Neste sentido, a Discricionariedade convergirá para a ideia de poder ou faculdade de escolher sobre uma de duas ou mais soluções possíveis ${ }^{13}$. Além desta, Lifante Vidal, arrimada em Dworkin, destaca que, diante da falta de padrões jurídicos que se prestem a guiar a decisão judicial, pode pensar-se na discricionariedade em sentido forte. Neste sentido, a decisão não se vinculará a qualquer padrão precedente ${ }^{14}$, embora, em nosso entender, deva guardar correspondência com a noção de juridicidade.

O quadro categorial exposto induz-nos a admi-

12 LIFANTE VIDAL, Isabel. Dos conceptos de discrecionalidad jurídica. Doxa. Cuadernos de Filosofía del Derecho, n. 25 , p. 417,2002

13 LIFANTE VIDAL, Isabel. Dos conceptos de discrecionalidad jurídica. Doxa. Cuadernos de Filosofía del Derecho, n. 25 , p. 417,2002

14 LIFANTE VIDAL, Isabel. Dos conceptos de discrecionalidad jurídica. Doxa. Cuadernos de Filosofía del Derecho, n. 25, p. 417-418, 2002. tir a Discricionariedade Judicial do civil law, como se vê nos sistemas jurídicos da Europa continental e do Brasil, e a do sistema common law, notoriamente anglo-americano. Se neste modelo de Direito a liberdade concedida ao Juiz faz parte de uma cultura jurídica forjada desde o século XIII, surgindo como problema metodológico cuja complexidade se radicará especialmente no âmbito dos hard cases, no outro, as características conceituais de Discricionariedade Judicial, a liberdade, a indeterminação do Direito e o poder, formarão o sistema problemático a ser enfrentado por uma metodologia que pretenda fixar as bases seguras da atividade jurisdicional. Os problemas adquirem maior dimensão quando se percebem distintos movimentos político-jurídicos que ou demonstram certa rebeldia à interpretação e aplicação de normas legais, como se vê entre os que advogam o alternativismo jurídico e os juízes para a democracia, ou claramente postulam a passagem do nosso modelo de Direito para o common law, num entendimento algo naïf sobre o caráter da Súmula vinculante, tudo, claro, em nome de uma atividade judicial que contribua "para o progresso social da sociedade (sic), fazendo avançar o Direito no rumo da liberdade, igualdade e fraternidade"15.

Para uma tentativa de dissolução do problema metodológico, impende, incialmente, sublinhar que a $l i$ berdade - ou como Castanheira Neves prefere, desvinculação $o^{16}$ — não quer simplesmente significar uma atuação judicial despegada de qualquer limite ou referencial de inerente juridicidade. Ou seja, queremos dizer que a Discricionariedade deriva de uma liberdade relativa, na medida em que se deve aferir os contornos de juridicidade da decisão judicial. Parece-nos, neste sentido, fugir completamente dos limites de Discricionariedade a decisão na qual o Juiz estabelece uma solução que conflitue com Leis, princípios e costumes sedimentados numa cultura jurídica ${ }^{17}$. O problema que aqui surge, então, é o de saber

15 MARQUES, Luiz Guilherme. Boca da Lei. Disponível em: $<$ http://www.amb.com.br/?secao=artigo_detalhe\&art_ id=105>. Acesso em: 10 mar. 2014.

16 NEVES, A. Castanheira. O problema da discricionariedade. In. NEVES, A. Castanheira. Digesta: escritos acerca do Direito, do pensamento jurídico, da sua metodologia e outros. Coimbra: Coimbra Editora, 1995. v. 1. p. 534.

17 No início de 2014, causou (justificada) celeuma a decisão de um Juiz de Brasília que, considerando ser a cannabis sativa uma droga recreativa, absolveu o réu acusado de tráfico ilícito de drogas. O magistrado faz expressa menção à Portaria 344/98, da ANVISA, que estabelece o controle sobre medicamentos e substâncias, considerando tratar-se de 
qual é a medida de liberdade concedida ao Juiz, de modo que suas decisões convirjam para a realização do Direito.

Castanheira Neves especula um arranjo metodológico para o problema da liberdade (na discricionariedade) a partir da contraposição de desvinculação à ideia de vinculação (do Juiz à norma regrada em Lei). Ora, por esse critério, o Juiz estaria irremediavelmente preso ao processo lógico-subsuntivo de aplicação da Lei. Então,

Decisão juridicamente vinculada é a decisão a proferir mediante a aplicação subsuntiva de uma norma legal, e juridicamente desvinculada a decisão que houver de reconhecer-se como válida (juridicamente válida) embora não tenha sido subsuntivamente deduzida, directa ou indirectamente, de uma norma legal, ou, em termos mais amplos, de uma norma jurídica. ${ }^{18}$

Este será, portanto, um critério negativo de Discricionariedade. Ou, de outra forma, o contrário de Discricionariedade. Mas ao indicar essa referência conceitual para a categoria, o jurisfilósofo conimbricense adverte-nos que a falta de vinculação da Discricionariedade Judicial não significa "um espaço vazio de Direito", ou que as decisões emanadas pelo recurso a essa prerrogativa não se projetam "para além do domínio coberto pelo direito, pois [...] a decisão discricionária surge no seio da ordem jurídica e como modo jurídico de juízo ou de conduta só que com conteúdo em si não jurídico, por não ter sido ele obtido pela imediata aplicação de critérios jurídicos." ${ }^{19}$ Por outras palavras, o ato de Discricionariedade Judicial não deriva imediatamente de critério legal, mas não pode

"um ato administrativo que restringe direitos, [carecendo] de qualquer motivação por parte do Estado e não justifica os motivos pelos quais incluem a restrição de uso e comércio de várias substâncias, em especial algumas contidas na lista F, como o THC, o que, de plano, demonstra a ilegalidade do ato administrativo." Numa palavra, não concorda que a Portaria do órgão do Ministério da Saúde inclua a maconha entre as drogas proibidas, apesar de, pela sistemática penal, aquele regramento preencher a norma penal em branco contida no art. 33, da Lei 11.343/06. COUTINHO, Felipe. Juiz considera maconha 'recreativa' e absolve traficante. Disponível em: <http://www1.folha.uol.com.br/ cotidiano/2014/01/1404517-juiz-considera-maconha-recreativa-e-absolve-traficante-confesso.shtml>. Acesso em: 16 mar. 2014.

18 NEVES, A. Castanheira. O problema da discricionariedade. In. NEVES, A. Castanheira. Digesta: escritos acerca do Direito, do pensamento jurídico, da sua metodologia e outros. Coimbra: Coimbra Editora, 1995. v. 1. p. 534.

19 NEVES, A. Castanheira. O problema da discricionariedade. In. NEVES, A. Castanheira. Digesta: escritos acerca do Direito, do pensamento jurídico, da sua metodologia e outros. Coimbra: Coimbra Editora, 1995. v. 1. p. 535.
— não deve - renunciar por completo às determinações político-jurídicas da Lei, nela encontrando o estabelecimento de seu fundamento e limites ${ }^{20}$. $\mathrm{O}$ art. $4^{\circ}$, da Lei de Introdução ao Código Civil (Lei 4.657/42), v.g., concede uma área de liberdade discricionária, dispondo que, em caso de omissão da Lei, "o juiz decidirá o caso de acordo com a analogia, os costumes e os princípios gerais do direito"21; a individualização da pena, segundo dispõe a Constituição, será regulada por Lei (art. $\left.5^{\circ}, \mathrm{XLVI}\right)$, cabendo ao Juiz fazer a escolha (discricionária) daquela que seja adequada e necessária para dar cumprimento ao objetivo preventivo-especial do Direito Penal, dosando-a proporcionalmente ao grau de culpabilidade do réu.

Em segundo lugar, temos de considerar que, pelo critério de contraposição de vinculação à desvinculação, vamos encontrar, no primeiro caso, uma área de decidibilidade restrita a uma só solução jurídica, depreendida pelo processo subsuntivo da regra legal; ao passo que, nos casos de autorizada e fundada Discricionariedade, o órgão decisor encontrará várias alternativas, ou várias possibilidades de decisões válidas, autorizadas por norma legal. "Todas elas - esclarece Castanheira Neves — seriam para essa norma juridicamente equivalentes, já que cada uma dessas decisões era uma sua realização possível, surgindo assim perante elas (por parte da norma) como que uma situação de indiferença jurídica a implicar que qualquer das decisões fosse válida, que se oferecessem todas como juridicamente válidas."22 Se é assim, então teremos de convir que o poder Discricionário Judicial concede uma liberdade para fazer-se uma opção dentre as várias alternativas possíveis.

Por fim, essa liberdade para a escolha de uma decisão dentre várias possíveis não se confunde com um puro arbítrio. O Juiz, antes de escolher aleatoriamente a solução para o problema jurídico, fará sua opção sobre aquela que, equacionada segundo os estalões de juridicidade ou de Direito, tenha aceitabilidade e efetividade não apenas

NEVES, A. Castanheira. O problema da discricionariedade. In. NEVES, A. Castanheira. Digesta: escritos acerca do Direito, do pensamento jurídico, da sua metodologia e outros. Coimbra: Coimbra Editora, 1995. v.1. p. 536.

21 BRASIL. Lei 4.657/42. Disponível em: <http://www.planalto.gov.br/ccivil_03/decreto-lei/Del4657.htm>. Acesso em: 18 mar. 2014.

22 NEVES, A. Castanheira. O problema da discricionariedade. In. NEVES, A. Castanheira. Digesta: escritos acerca do Direito, do pensamento jurídico, da sua metodologia e outros. Coimbra: Coimbra Editora, 1995. v. 1. p. 534. 
no mundo jurídico, mas na comunidade. Por esse motivo, será lícito afirmar, com Castanheira Neves, que a liberdade discricionária implica uma desvinculação do Juiz a uma solução única alcançável pela subsunção, mas não "uma desvinculação perante o direito ou do jurídico em geral; assim, pode dizer-se que a Discricionariedade Judicial será "uma liberdade para o cumprimento do dever"; o que significa dizer que a atuação judicial estará vinculada ao cumprimento do dever, "um dever que encontraria o seu fundamento numa intencionalidade à ordem jurídica, ou mesmo ao direito, o qual a decisão discricionária, a seu modo, também haveria de realizar." ${ }^{23}$ Assim, em razão do caráter preventivo-especial da pena, seria um completo absurdo para os padrões do sistema jurídico-penal em vigor que, v.g., o Juiz, usando de seu poder discricionário, aplicasse menor carga de (res)socialização à condenação do réu agente de prática delituosa flagrantemente abjeta e contrastante com os valores de uma comunidade.

\section{Constitucionalização dos problemas jurídi- cos e ativismo judicial}

A última onda de constitucionalização, iniciada após a Segunda Guerra Mundial, consolida o modelo de Constituição que não apenas encarta os direitos fundamentais individuais e sociais, mas, também, princípios fundamentais com fortes traços ontológicos e axiológicos. As Constituições alemãs, imbuídas do humanismo jurídico reconhecido pela Declaração dos Direitos do Homem, inscrevem a dignidade da pessoa humana; a portuguesa, de 1976 abre a fundamentação do Estado com princípios, o que, de forma parecida, veremos na Constituição espanhola, de 1978. Não é diferente o que se vê na Constituição Cidadã, responsável por implantar as bases de redemocratização do Brasil, caracterizada, por um lado, pela abstenção estatal de intromissão na área de liberdade individual, que entra em direta concordância, v.g., com os princípios da dignidade da pessoa humana, da liberdade, da igualdade, da universalidade e da tolerância; caracterizando, em suma, a ideia de liberdade negativa (o liberty from, formulado por Isaiah Berlin ${ }^{24}$ ),

23 NEVES, A. Castanheira. O problema da discricionariedade. In. NEVES, A. Castanheira. Digesta: escritos acerca do Direito, do pensamento jurídico, da sua metodologia e outros. Coimbra: Coimbra Editora, 1995. v. 1 p. 540.

24 BERLIN, Isaiah. Cuatro ensayos sobre la libertad. Tradução de Julio Bayon. Madrid: Alianza Editorial, 1998. p. 220-231. significando que deve atribuir-se às pessoas o Direito de estar livre de (intromissões estatais). Por outro lado, nossa Constituição também avança sobre a previsão de Direitos sociais, aqueles que dependem das prestações estatais e vão conformar a ideia de liberdade positiva (ou, segundo a formulação de Berlin, liberty $t 0^{25}$ ), ou seja a liberdade para a autorrealização.

A ideia constitucional de liberdade é complexa. Implica a concessão de autonomia para o homem, que se realiza pela não intervenção do Estado na esfera da individualidade, mas, também, pela atividade estatal naquelas áreas fundamentais para o aperfeiçoamento - educação, saúde, previdência, segurança, acesso à Justiça etc. Os valores integrantes dessa intenção político-jurídica de realização do homem (ou de seu aperfeiçoamento como ser humano) não cabem, portanto, em regras, nem num rigoroso esquema programático. Por essa razão a admissão dos princípios ${ }^{26}$ colmata a vida político-jurídica do Estado num nível em que se acham presentes valores ético-sociais ${ }^{27}$. Essa situação modela o novo Estado, no qual observamos uma verdadeira viragem de paradigmas por sairmos da democracia formal (essencialmente marcada pelo direito de eleger e ser eleito) rumo à democracia material (onde se estruturam condições para o aperfeiçoamento do indivíduo e da sociedade); de maneira que o Estado já não será apenas democrático de direito, mas um Estado adjetivado por valores de relevo humano e social.

Essas características do novo constitucionalismo autorizam-nos a reconhecer maior dinamismo ao sistema jurídico-constitucional. Não exatamente em sua estrutura interna, pois que a Constituição é rígida e o processo para sua alteração apresenta redobrados mecanismos de

25 BERLIN, Isaiah. Cuatro ensayos sobre la libertad. Tradução de Julio Bayon. Madrid: Alianza Editorial, 1998. p. 231236.

26 ÁVILA, Humberto. "Neoconstitucionalismo": entre a "ciência do Direito" e o "Direito da ciência". Revista Eletrônica de Direito do Estado, Salvador: Instituto Brasileiro de Direito Público, n. 17, jan./mar. 2009, confirma a inserção da Constituição brasileira no neoconstitucionalismo, destacando as distintas funções das regras e princípios constitucionais, sendo que estes auxiliam na interpretação e integração das regras infraconstitucionais.

27 BARROSO, Luís Roberto. Fundamentos teóricos e filosóficos do novo Direito Constitucional brasileiro (pós-modernidade, teoria crítica e pós-positivismo). Revista Diálogo Jurídico, Salvador, ano 1, v. 1, n. 6, set. 2006, 32, refere que os "Princípios contêm, normalmente, uma maior carga valorativa, um fundamento ético, uma decisão política relevante, e indicam uma determinada direção a seguir." 
segurança, de modo que se torne difícil imprimirem-se reformas ditadas, v.g., pelo programa político de um governo ${ }^{28}$. Mas pela possibilidade constitucionalizarem-se matérias regradas no âmbito infraconstitucional ou que sequer tiveram um tratamento legislativo ${ }^{29}$.

A Constituição e as normas positivadas em Leis são assimétricas, seja em razão do caráter fragmentário do Direito, seja pelo fato de tornarem-se desgastadas pelo decurso do tempo, necessitando de ajustamentos que reflitam a atualidade histórico-social. Essa circunstância é sensivelmente clara na área do Direito punitivo (em que incluímos o Direito Penal, o Direito Processual Penal e a execução penal). Por um lado, em razão de termos legislações anteriores a 1988 que, mesmo passando por alterações, estão em descompasso com o corpus iuris fundado pela Constituição; por outro, pelo fato de que vários fatores exercem direta influência sobre o monopólio da tutela penal de bens jurídicos, exigindo políticas de criminalização ou de descriminalização, e de reforço de instrumentos a tornarem o processo apto à consecução

28 Pelo menos em tese. Nossa experiência político-partidária não revela alternância dos quadros programáticos, nem uma oposição que permita o refreio do aparelhamento estatal e do controle da vida política. RAMOS, Carlos Henrique. Mutação constitucional: Constituição e identidade constitucional evolutiva. Curitiba: Juruá, 2013. p. 227, refere, a propósito: "A proliferação de partidos políticos gera um fisiologismo que esconde as verdadeiras ideologias, fazendo com que, entre nós, a coalisão partidária não seja formada por razões puramente ideológicas. Todos se assumem como de "centro-esquerda", como se não houvesse "direita" no Brasil.

29 BARROSO, Luís Roberto. Neoconstitucionalismo e constitucionalização do Direito (o triunfo tardio do Direito Constitucional no Brasil). Revista de Direito Constitucional e Internacional. Doutrinas Essenciais de Direito Constitucional. v. 1, maio 2011. Disponível em: <http://jus.com.br/ $\operatorname{artigos} / 7547 /$ neoconstitucionalismo-e-constitucionalizacao-do-direito $>$. Acesso em: 25 mar. 2014, sintetiza a ideia de constitucionalização da seguinte forma: "A constitucionalização [...] expressa a irradiação dos valores constitucionais pelo sistema jurídico. Esta difusão da Lei Maior pelo ordenamento se dá por via da jurisdição constitucional, que abrange a aplicação direta da Constituição a determinadas questões; a declaração de inconstitucionalidade de normas com ela incompatíveis; e a interpretação conforma a Constituição, para atribuição de sentido às normas jurídicas em geral. No caso brasileiro, deve-se enfatizar a jurisdição constitucional é exercida amplamente: do juiz estadual ao Supremo Tribunal Federal, todos interpretam a Constituição, podendo, inclusive, recusar aplicação à lei ou outro ato normativo que considerem inconstitucional." Esta definição, contudo, não exaure a noção total de constitucionalização, nem aflora as questões problemáticas que aqui serão tratadas. dos fins do Direito Penal. É possível pensar-se, v.g., que os avanços tecnológicos facultam medidas cautelares menos drásticas do que a prisão preventiva, como se vê pela adoção do monitoramento eletrônico do indiciado ou do réu sob medida cautelar coercitiva; mas a vida artificial, que se desenvolve no ambiente virtual da internet, é pródiga em criar novos perigos para as pessoas, reivindicando tanto políticas de criminalização, como de criação de medidas cautelares necessárias para impedir os riscos, bem como para constituir matéria de prova.

Ora, nesse campo entremeado de armadilhas, algumas delas plantadas pelo legislador penal, quando tenta criar uma sensação de paz por meio da criminalização (sem que para isso tenha o arrimo da criminologia e da máxima que entende o Direito punitivo como a ultima ratio do sistema jurídico), tem-se tornado frequente a realização do controle de constitucionalidade de normas jurídico-penais, em boa verdade escritas com má técnica legislativa e jurídica. Mas não só. Os tribunais, especialmente o STF, que acaba por estabelecer modelos interpretativos de normas legais, chancelando ou não sua constitucionalidade, ultrapassam os lindes exegéticos e mesmo de uma hermenêutica crítica para dissentirem da política criminal formulada por processos legislativos formal e materialmente sustentáveis. Atraem para sua esfera de realização político-criminal, por meio da constitucionalização, matérias estranhas ao controle constitucional, ou que não reivindicam a aferição de sua conformidade com a Constituição.

A postura de nosso judiciário, que trilha caminhos distintos para a concretização do Direito Penal (não se podendo falar, por isso, de uma política criminal consolidada pelas decisões judiciais, mas de experimentação de soluções que, a todas as luzes, quebram o desenvolvimento metódico de entendimentos jurídicos), dizendo-se proativo, democrático, preocupado com a Justiça social, garantista, enfeixando, portanto, o movimento denominado de Ativismo Judicial, está longe de configurar uma jurisdição constitucional dedicada a "interpretar a Constituição, expandindo o seu sentido e alcance", como refere Barroso $^{30}$. Não trata propriamente de estabelecer marcos definidores de normas constitucionais, ou de fazer o exa-

BARROSO, Luís Roberto. Judicialização, ativismo judicial e legitimidade democrática. Disponível em: <www.oab.org.br/ editora/revista/users/revista/1235066670174218181901. pdf $>$. Acesso em: 19 fev. 2014. 
me de constitucionalidade de regras legais quando para isso é provocado ${ }^{31}$, mas, atua, como eufemisticamente podemos referir, proativamente, intervindo, de maneira difusa, em questões penais ou processuais penais que, a rigor, não reclamam sua conformação à Constituição. Por outras palavras, essa postura judicial visa tornar constitucional matéria que, em sua essência, não reclama uma leitura interpretativa através das lupas da Constituição.

$\mathrm{O}$ excessivo manejo de princípios fundamentais - que é excessivo por se os empregarem corriqueira e indistintamente para a generalidade dos problemas jurídicos ao invés de se os reservar para os casos em que se requeira a otimização das regras do Direito infraconstitucional, para que se as integre ao sistema jurídico-constitucional - vai para além, portanto, do exame de constitucionalidade das regras legais: por um lado, é uma forma de aplacar algumas das deficiências dos legisladores, regrando aquilo que não chegou a ser contemplado pela atividade legislativa e que, à evidência, carecia de regramento; por outro, o Ativismo assumir-se-á como fator de catalisação da formação de uma política criminal ditada pelos Tribunais, ou seja, diretamente pelos aplicadores do Direito. Mas essa propensão não é isenta de uma extensa teia problemática, só perceptível quando incluímos no Ativismo Judicial as decisões que transbordam o âmbito de controle de constitucionalidade ${ }^{32}$.

A constitucionalização de matérias as quais, a toda evidência, estariam fora da órbita problemática de adequação constitucional, como vemos, v.g., na edição da Súmula vinculante 11, que trata do uso das algemas, vulgariza a atuação do STF. Mas, também, enfraquece o eixo ético-jurídico da Constituição, especialmente pelo fato de

31 Aliás, STRECK, Lênio. O ativismo judicial existe ou é imaginação de alguns? Disponível em: <http://www.conjur.com. br/2013-jun-13/senso-incomum-ativismo-existe-ou-imaginação-alguns>. Acesso em: 19 fev. 2014, ao fazer aproximações conceituais do Ativismo, refere: "é necessário dizer que a simples declaração de uma inconstitucionalidade não quer dizer ativismo ou não ativismo. $\mathrm{O}$ controle de constitucionalidade é justamente a função precípua e democrática de uma corte constitucional", conduzindo-nos a entender que este fenômeno está para além do exame de controle de constitucionalidade.

32 A propósito, BARROSO, Luís Roberto. Judicialização, ativismo judicial e legitimidade democrática. Disponível em: <www.oab.org.br/editora/revista/users/revista/1235066670174218181901.pdf $>$. Acesso em: 19 fev. 2014. rebate todas as críticas normalmente feitas ao Ativismo, mas parte de sua definição estreita, como já anteriormente referido. que, na falta de regras constitucionais em direto conflito com o ordenamento infraconstitucional (e, em boa verdade, não se encontrará essa colisão quando pensamos no uso de algemas, que não é, repitamos, problema constitucional mas, simplesmente, regra de segurança), os magistrados só poderão laborar mediante grande esforço argumentativo para abrigar sua iniciativa político-criminal em algum dos princípios fundamentais. E quando não o encontram, sempre se socorrem do princípio que é a panaceia para todos os problemas, o da dignidade da pessoa humana. Mas afinal, podemos nos socorrer a qualquer instante dos princípios fundamentais?

Os princípios da Constituição, segundo se depreende da dogmática e de uma consolidada doutrina ${ }^{33}$, são normas jurídicas com alto grau de generalidade, e por isso, antes de fundarem-se exclusivamente como mandados deônticos, neles vemos hipóteses de concreção somente "dentro das possibilidades jurídicas e reais existentes" 34 . Não se aplicam ordinariamente, como determinações de dever-ser, mas, prioritariamente ${ }^{35}$, quando houver a necessidade de interpretarem-se regras infraconstitucionais e integrá-las ao telos constitucional ${ }^{36}$. São, como denomina Alexy, mandados de otimização ${ }^{37}$. Já por isso, seu manejo não deve ser ordinário, mas extraordinário, naquelas situações em que a aplicação de uma regra legal é problemática, reivindicando a atestação de sua constitucionalidade. Contudo, o que temos assistido sob a roupagem de Ativismo Judicial é a inversão dessa

ALEXY, Robert. Teoria de los derechos fundamentales. Trad. ao espanhol de Ernesto Garzón Valdés. Madri: Centro de Estudios Constitucionales, 1997. p. 83 e ss.

34 ALEXY, Robert. Teoria de los derechos fundamentales. Trad. ao espanhol de Ernesto Garzón Valdés. Madri: Centro de Estudios Constitucionales, 1997. p. 86.

35 A ressalva deve-se à hipótese de que, como orientações jusumanistas, vemos possível a hipótese de o legislador orientar-se pelos princípios.

36 ÁVILA, Humberto. "Neoconstitucionalismo": entre a "ciência do Direito" e o "Direito da ciência". Revista Eletrônica de Direito do Estado, Salvador: Instituto Brasileiro de Direito Público, n. 17, jan./mar. 2009. ao tratar da função dos princípios fundamentais, refere que "servem para interpretar, bloquear e integrar as regras infraconstitucionais existentes. Os princípios constitucionais, no entanto, só exercem a sua função de bloqueio, destinada a afastar a regra legal, quando ela for efetivamente incompatível com o estado ideal cuja promoção é por eles determinada."

37 ÁVILA, Humberto. "Neoconstitucionalismo": entre a "ciência do Direito" e o "Direito da ciência". Revista Eletrônica de Direito do Estado, Salvador: Instituto Brasileiro de Direito Público, n. 17, jan./mar. 2009. 
lógica, de maneira que o Juiz, não concordando com os resultados possíveis em razão da aplicação de regra legal, substitui-a pela argumentação alcançada a partir da definição de um princípio ${ }^{38}$.

As (re)definições desenvolvidas ao longo da argumentação jurídica das decisões, têm, no entanto, outras consequências para além da já citada inversão, nomeadamente quando o Juiz pretere a aplicação da regra legal para constitucionalizar a situação problemática. Diz-se, então, que a nova postura judicial põe em risco o princípio democrático, uma vez que os Juízes passam a ocupar o locus caracteristicamente reservado ao legislador, que é o agente político constituído pelo mandato outorgado pelos cidadãos. A situação é sensivelmente percebida na área do Direito que estamos a tratar, em que observamos um choque frontal entre a política criminal legislada e aquela estruturada pelos Juízes. É exemplo disso o novo conteúdo dado pelo STF ao princípio da individualização da pena, que conferiria "irreprimível discricionariedade" ao Juiz sentenciante, inclusive para, ao aplicar a sanção, escolher aquela que lhe pareça mais adequada, mesmo que não prevista em $\mathrm{Lei}^{39}$. Observe-se que, neste exem-

38 A propósito, ÁVILA, Humberto. "Neoconstitucionalismo": entre a "ciência do Direito" e o "Direito da ciência". Revista Eletrônica de Direito do Estado, Salvador: Instituto Brasileiro de Direito Público, n. 17, jan./mar. 2009. afirma que "Ele [o aplicador do Direito] não pode deixar de aplicar uma regra infraconstitucional simplesmente deixando-a de lado e pulando para o plano constitucional, por não concordar com a consequência a ser desencadeada pela ocorrência do fato previsto na sua hipótese."

39 No Habeas Corpus 97256-STF, o relator, Min. Ayres Britto, apoia-se no princípio da individualização da pena e na prescrição das modalidades punitivas descritas no art. $5^{\circ}$ XLVI, CR ("a lei regulará a individualização da pena e adotará, entre outras, as seguintes: a) privação ou restrição da liberdade; b) perda de bens; c) multa; d) prestação social alternativa; e) suspensão ou interdição de direitos"), para inquinar de inconstitucional a regra então contida no $\$ 4^{\circ}$, do art. 33 , da Lei $11343 / 06$, que não permitia a conversão da pena de reclusão por restritivas de direito. Em seu entender, a Lei comum não poderia subtrair ao Juiz o poder-dever de atribuir ao réu pena que lhe parecer "como expressão de um concreto balanceamento ou de uma empírica ponderação [...] implicando essa ponderação em concreto a opção jurídico-positiva pela prevalência do razoável sobre o racional". Mais adiante, o antigo Ministro do STF estabelece um grau de equivalência entre discricionariedade e liberdade de decisão, referindo: "o Juiz sentenciante se movimentaria com irreprimível discricionariedade entre aplicar a pena de privação ou de restrição de liberdade e outra que já não tivesse por objeto esse bem jurídico maior da liberdade física do sentenciado, sem prejuízo de que a proposição da lei pudesse ser endurecedora nos crimes plo, a discricionariedade judicial vai ao ponto de mudar o sentido do princípio constitucional.

Como se pode observar, essa discricionariedade discrepa da noção de Discricionariedade Judicial, não guardando qualquer relação com seus fundamentos. As decisões delas emanadas, não operam metodicamente uma argumentação juridicamente refletida (sobre as fontes do Direito ou de juridicidade), mas são prenhes de muito subjetivismo e de nenhum critério material que as torne plausíveis. Essa circunstância, conforme observa Ávila, leva “à eliminação ou severa redução do caráter heterolimitador do Direito." 40

Ora, a ampliação do decisionismo judicial por meio da aplicação direta de princípios constitucionais essencialmente abertos ao variado desenvolvimento argumentativo - no lugar de regras legais, causa inegáveis riscos. No âmbito jurídico-cível, relativamente aos diretos receptores de uma decisão — que será a norma jurídico-positiva casuística para um caso concreto - pelo fato de os interessados não poderem prever a metódica construção da norma jurídica (quebrando-se, então, a ideia de segurança jurídica); enquanto na área jurídico-penal, os riscos decorrem da possível colisão entre a política criminal orientadora dos fins de um sistema jurídico-penal e a política criminal individualizada pelo Juiz ou Tribunal. Os reflexos dessa postura serão mais drásticos na área da Justiça criminal, uma vez que as decisões emanadas da liberalidade judicial destinar-se-ão, em última análise, à coletividade, que é carecedora da atividade estatal que promova paz e segurança por meio da tutela de bens jurídicos de relevo social.

A zona compromissória e de incertezas do Ativismo Judicial torna-se mais perceptível quando passamos a analisar algumas das posições sustentadas pelos tribunais superiores, que a seguir encetaremos.

enunciados na Constituição Federal." Ocorre que, a bem da verdade, o impedimento de conversão da pena para os casos de tráfico de drogas não impede a individualização da pena, que é levada a efeito por ocasião de sua dosagem. Além do mais, o enunciado do princípio mencionado é no sentido de que "a lei regulará a individualização da pena", ou seja, a Constituição defere a discricionariedade ao Juiz, mas dentro das balizas da Lei penal. Sobre a questão, ver: SABBÁ GUIMARÃES, Isaac. Lei antidrogas comentada. 6. ed. rev. atual. e ampl. Curitiba: Juruá, 2013. p. 120-125.

40 ÁVILA, Humberto. "Neoconstitucionalismo": entre a "ciência do Direito" e o "Direito da ciência". Revista Eletrônica de Direito do Estado, Salvador: Instituto Brasileiro de Direito Público, n. 17, jan./mar. 2009. 


\section{A política criminal ditada pelo ativismo judi- cial}

Apesar de muito difundida uma ideia de política criminal estruturada a partir dos tribunais, v.g., ao se falar da aplicação do princípio da insignificância e do perdão judicial, o fato é que esta não é apenas uma área prático-forense. Nem se pode dizer que tenha ali seu locus prioritário, já que as realizações político-criminais devem ingressar no discurso juscriminal sobre sólidas bases. $\mathrm{Na}$ lição de Correia, a política criminal "recolhe e valora os resultados da criminologia."41 Ou seja, os processos de criminalização e de descriminalização, a definição das finalidades das penas e de seu caráter preventivo e do modelo de execução penal - em suma, a "definição das estratégias de controlo social do fenómeno da criminalidade" ${ }^{\prime 2}$ - são dependentes dos elementos integrantes do fenômeno criminal estudados pela criminologia. Mas não só. Essa definição das estratégias levada a efeito num Estado democrático de direito não pode contrastar com os valores e diretrizes constitucionais. De forma que as opções político-criminais partem das fontes criminológicas, mas não cruzam os limites impostos pela Constituição ${ }^{43}$.

A política criminal tem seu lugar, como se vê, nas decisões formuladas pelo legislador penal. No entanto, ao perspectivar-se esta ciência do mundo jurídico a partir da nova hermenêutica, que antes de conformar-se ao processo silogístico, impõe ao órgão decisor o dever de estabelecer a solução para o problema jurídico convocando informações metajurídicas, passa-se a perceber que as concretizações político-criminais são realizadas pelos Juízes. O que nos leva a reconhecer sua importância na formulação da política criminal, na medida em que a

${ }^{41}$ CORREIA, Eduardo. Direito criminal. Coimbra: Livraria Almedina, 1996. v. 1.

42 DIAS, Jorge de Figueiredo. Direito penal: parte geral. 2.ed. portuguesa. São Paulo: Revista dos Tribunais; Coimbra: Coimbra Editora, 2007. T. 1. p. 19.

43 DIAS, Jorge de Figueiredo. Direito penal: parte geral. 2.ed. portuguesa. São Paulo: Revista dos Tribunais; Coimbra: Coimbra Editora, 2007. p. 35. O penalista português refere, a esse propósito, que a política criminal é "imanente ao sistema jurídico-constitucional”, não sendo exata, por isso, a afirmação de que ela "possa e deva fazer apelo directo e imediato ao sistema social como tal para estabelecimento das suas finalidades e das suas proposições. Exacto é antes que as finalidades e as proposições político-criminais devem, elas, também, ser procuradas e estabelecidas no interior do quadro de valores e de interesses que integram o consenso comunitário mediado e positivado pela Constituição.” desconstrução de antigos paradigmas e a construção de novos, plasmadas na jurisprudência, orientarão as estratégias de controle do fenômeno criminal.

$\mathrm{O}$ que se tem visto em nossa experiência jurídico-jurisdicional, no entanto, não é a pavimentação ordenada de uma jurisprudência apta a provocar (re)definições político-criminais, mas manifestações de ativismo e decisões de significativa rebeldia dos Juízes contra a Lei penal e, até mesmo, contra a Constituição. Num extremo, encontram-se as posições (caóticas) dos Juízes para democracia e dos alternativistas, que não chegam a criar postulados metodicamente ordenados de reforma dogmático-jurídica, mas revelam engajamento político-ideológico. Os Juízes democratas pregam uma maior independência do judiciário, tanto no plano estatal, como em relação a grupos "internos ou externos à Magistratura" ${ }^{44}$. Em tom notadamente marxista, os adeptos desse grupo preconizam "a defesa dos direitos dos menores, dos pobres e das minorias, na perspectiva de emancipação social dos desfavorecidos"45, um compromisso arriscado que conota parcialidade (quando, sabidamente, os Juízes devem promover a Justiça para todos). Seu ativismo vai a ponto de criticar políticas de criminalização, como se vê no Manifesto de repúdio às propostas de tipificação do crime de terrorismo, que, segundo lhes parece, são próprias de um "Estado penal segregacionista", que constituiria um "mecanismo de contenção das lutas sociais democráticas e eliminação seletiva de uma classe da população brasileira." ${ }^{36}$ Há quem, como Karam, apregoe ideias libertárias em nome, claro, da emancipação pessoal e do modelo de

44 ESTATUTO da AJD. Disponível em: <http://ajd.org.br/ quem_somos_estatuto.php $>$. Acesso em: 6 abr. 2014.

45 ESTATUTO da AJD. Disponível em: <http://ajd.org.br/ quem_somos_estatuto.php >. Acesso em: 6 abr. 2014 ..

46 MANIFESTO de repúdio às propostas de tipificação do crime de Terrorismo. Disponível em: <http://ajd.org.br/ documentos_ver.php?idConteudo $=140>$. Acesso em: 29 nov. 2013. É de frisar-se que os projetos não atentam contra os grupos de pressão e as manifestações de rua, mas pró́bem a provocação de "terror e pânico generalizado mediante ofensa à vida, à integridade física ou à saúde ou à privação de liberdade de pessoa, por motivo ideológico, religioso, político ou de preconceito racial ou étnico" (Projeto Romero Jucá); "incendiar, depredar, saquear, destruir ou explodir meios de transporte ou qualquer bem público ou privado" (Projeto Miro Teixeira). Ambos visam a tutela de bens com dignidade penal e arrimam-se nos princípios constitucionais da liberdade de expressão (art. $5^{\circ}, \mathrm{IX}, \mathrm{CR}$ ) e da liberdade de reunião, desde que seja pacífica (art. $5^{\circ}$, XVI, CR). Portanto, ditos projetos não colocam em causa o princípio democrático do poder político. 
Estado democrático, como a da descriminalização do tráfico de drogas ${ }^{47}$, sem considerar qualquer estudo criminológico sobre a matéria, nem, muito menos, que a questão é político-criminalmente definida na Constituição (art. $5^{\circ}$, XLIII) e na Convenção de Viena, contra o tráfico ilícito de entorpecentes e de substâncias psicotrópicas, de 1988, da qual somos signatários e que foi formalmente incluída em nosso corpus iuris (Decreto n. ${ }^{\circ}$ 154/91). Esses discursos, desenvolvidos precariamente com base em lugares-comuns, não atestados metodologicamente, têm repercutido em decisões que afrontam regras legais e a Constituição, como no caso em que a absolvição de traficante fulcra-se no convencimento pessoal (e não do Juiz a partir do conteúdo probatório) de que o comércio da cannabis sativa não deve ser proibido. Ou, quando o Juiz catarinense João Marcos Buch relaxa a prisão de um autor de furto não em razão de abuso de autoridade ou de ilegalidade do ato coercitivo, mas porque aquele foi detido por populares, que se mostravam "pessoas nutridas por sentimento paranoico coletivo (sic)", e passaram a agredi-lo. O magistrado observa que "Os novos padrões de civilidade e os fundamentos do Estado democrático de direito não permitem, em absoluto, a medieval "justiça pelas próprias mãos." 48

Noutro polo, estão as decisões do STF, tendentes a constitucionalizar matérias ordinárias que, em geral, não requerem o controle de constitucionalidade nem, a rigor, podem ser categorizadas como casos difíceis. Diga-se, aliás, que no julgado do HC 95.009-4/SP, o então Ministro Eros Grau repelia, terminantemente, a aplicação do princípio da proporcionalidade, o qual leva ao entendimento de que não haveria direitos absolutos; o Juiz que se socorre desse "postulado normativo" para interpretar o Direito, dirá que ele existe, mas nem sempre é aplicável, enquanto exalça em suas decisões a "atividade persecutória do Estado" e a "supremacia do interesse público sobre o privado". Em arremate de seu raciocínio, Grau afirmava que o correto é dar prevalência ao "direito à liberdade em detrimento do direito de acusar"49. Mas nessa suma,

47 KARAM, Maria Lúcia. Drogas e redução de danos. Revista Brasileira de Ciências Criminais, São Paulo, n. 64, p. 128144, jan./fev. 2007.

48 JUÍZES PARA A DEMOCRACIA. Decisões: prisão em flagrante. Disponível em: <http://www.ajd.org.br/decisoes_ver.php?idConteudo=29>. Acesso em: 28 nov. 2013. BRASIL. Supremo Tribunal Federal. HC 95.009-4/SP. Rel. Min. Eros Grau. Disponível em: <http://www.stf.jus.br/ contudo, não invectivava contra a constitucionalização vulgarizada dos problemas penais, mas desenvolvia, tout court, a absolutização da esfera de individualidade, sem considerar os interesses da coletividade pois que, em caso de conflito entre esses dois âmbitos, deverá prevalecer o preceito "garantidor da liberdade sobre o que fundamenta sua supressão." ${ }^{50}$

A posição de quase completo consenso dos magistrados das Cortes Superiores sobre essa linha argumentativa parte da sacramentalização da esfera de individualidade, ora em nome do princípio da presunção da inocência, ora invocando-se o princípio da dignidade da pessoa humana, que são aplicados como instrumentos resolutivos de problemas jurídicos, nos quais nem sempre se evidenciam colisões de princípios ${ }^{51}$. $\mathrm{O}$ caso Pimenta Neves é paradigmático: o jornalista confessou ter matado a namorada Sandra Gomide, em 20 de agosto de 2000; nunca apresentou tese de exclusão de antijuridicidade, de forma que, o julgamento de dezembro de 2006, com veredicto condenatório, não teria hipótese de reforma (não quanto ao mérito); mesmo assim, Pimenta Neves obteve o writ de habeas corpus (HC 72726-STJ), com base na aplicação do princípio da presunção da inocência (art. $5^{\circ}$, LVII, CR $)^{52}$, mesmo que a verdade material já estivesse concretizada e que, diante do princípio da soberania do júri popular, não se pudesse alterar a condenação.

Ao que parece, os Juízes tornaram-se insensíveis às tragédias que assolam inumeráveis pessoas sujeitas à criminalidade grave, assumindo posições político-criminais baseadas em antigos postulados da sociologia marxista, que atribuem à sociedade a responsabilidade pelos criminosos que nela habitam. Arcar com a situação

arquivo/cms/noticiaNoticiaStf/anexo/hc95009EG.pdf>. Acesso em: 08 abr. 2014.

50 BRASIL. Supremo Tribunal Federal. HC 95.009-4/SP. Rel. Min. Eros Grau. Disponível em: <http://www.stf.jus.br/ arquivo/cms/noticiaNoticiaStf/anexo/hc95009EG.pdf>. Acesso em: 08 abr. 2014.

51 Em muitos julgados, o mesmo Min. Eros Grau considerou inconstitucional a prisão preventiva ex lege prevista no art. 44, da Lei 11.343/06, alicerçando-se na aplicação dos princípios da presunção da inocência, do devido processo legal e da dignidade da pessoa humana, sem sequer se ocupar do enunciado contido no art. $5^{\circ}$, XLIII, da CR (v.g. HC 100.872-MC/MG). Este julgado serviu de paradigma para muitos outros daquela Casa Excelsa (v.g. HC 100.959/TO, rel. Min. Celso de Mello).

52 BRASIL. Supremo Tribunal de Justiça. HC 72726. Disponível em: <http://stj.jusbrasil.com.br/jurisprudencia/6275/ habeas-corpus-hc-72726>. Acesso em: 10 abr. 2014. 
criminal é, portanto, o ônus que se lhe atribui em nome de falaciosos fundamentos jusumanistas, como a já tão desgastada dignidade da pessoa humana. Assim, em momento algum ponderam os interesses da coletividade relativamente à paz, à segurança, à Justiça —, ao fim e ao cabo com o mesmo peso constitucional que os direitos individuais. Esquecem-se, em suma, que a Constituição deve ser interpretada segundo o princípio da unidade de que nos fala Hesse, de acordo com o qual é necessário evitarem-se colisões entre normas constitucionais ${ }^{53}$, fazendo equacionamentos de concordância prática ${ }^{54}$, dos quais se possam deduzir realizações do Direito possível, aquele que se compagina com uma realidade histórico-social.

\section{Considerações finais}

É interessante notar que a viragem constitucional brasileira não ficou historicamente limitada aos fatos políticos e jurídicos ocorridos há vinte e cinco anos. A Constituição ainda contrasta com um sistema jurídico-legal de grandes assimetrias. Há muito por fazer, inclusive no âmbito da política criminal, já que, de uma forma geral, nem o Código Penal nem o Código de Processo Penal se alinham às diretrizes constitucionais. Por um lado, há de se pensar em políticas de descriminalização, especialmente de condutas que hoje seriam melhor tratadas pelo Direito civil ou administrativo. Não se vê, hoje, a necessidade de punirem-se condutas como a do estelionato por emissão de cheque, nem carência de tutela penal para as condutas contravencionais. Mas, também, há de se pensar em políticas de cri-

53 HESSE, Konrad. Escritos de derecho constitucional. 2. ed. Seleção, tradução e introdução de Pedro Cruz Villalón. Madri: Centro de Estudios Constitucionales, 1992. p. 45.

54 Em algumas situações, o balanceamento entre as normas jurídico-constitucionais - quando, de fato, a ele o Juiz é levado por imposição da situação problemática — pode determinar maior peso para os interesses da coletividade, sem que, por isso, haja irremediável negação de direitos individuais. A propósito disso, NOVAIS, Jorge Reis. Direitos fundamentais: trunfos contra a maioria. Coimbra: Coimbra Editora, 2006. p. 33, refere que "o fundamento da eventual prevalência da posição da maioria não reside no argumento maioritário - precisamente porque os direitos fundamentais são constitucionalmente reconhecidos como direitos contra a maioria - , mas sim no resultado de uma ponderação de bens desenvolvida à luz dos parâmetros constitucionais e através da qual se atribua a um outro bem igualmente digno de proteção, em circunstâncias em que essa compreensão seja exigível, uma relevância susceptível de justificar a restrição do direito fundamental". minalização, de fenômenos como o do terrorismo, que, por sinal, é já tratada na Constituição (art. $5^{\circ}$, XLIII). Por outro lado, nosso processo penal e, fundamentalmente, nossa experiência jurídico-processual, cristalizam circunstâncias anômalas para os intervenientes processuais, existindo um órgão acusador que também deve zelar pela regularidade processual, sendo, pois, fiscal do processo, e um Juiz que se intromete arriscadamente na produção de prova, tomando testemunhos, interrogando e podendo produzir provas de ofício ( v.g., podendo determinar a produção antecipada de provas e quebrar o sigilo das comunicações), o que, inegavelmente, compromete a imparcialidade.

Apesar disso, o legislador pouco tem feito para mitigar as defasagens, o que vem servindo de pretexto para uma atuação judicial mais contundente, a partir de uma verticalização do tratamento dos problemas jurídicos, por meio do manejo de normas constitucionais. Mas, ao apoiarem-se exclusivamente no sistema de princípios inscrito na Magna Carta, muitas vezes pretendendo constitucionalizar matérias que não reclamam o controle constitucional, os Juízes deram um sentido absolutamente estranho à noção de Discricionariedade Judicial. Declaram-se Ativistas de um regime jurídico mais democrático e preocupado com a promoção social sem que, no entanto, se apercebam do paradoxo aí emergente. Em nome da democracia, colocam em causa o princípio democrático; ao tratarem dos inúmeros flagelos sociais pela via penal, criam desassossego e insatisfação da comunidade. Desprezam a circunstância da criminalidade grave, que, em 2012, causou a morte de 50.108 pessoas $^{55}$, ou quase a metade das vítimas da guerra civil na Síria entre 2011 e 2013 . Isso representa um índice de 25,8 mortes por cada cem mil habitantes, que é bastante significativo se comparado com os índices do Peru, Chile, Uruguai e Argentina (menos de 10 homicídios por cada 100 mil habitantes), com o Paraguai e o México (menos de 20 homicídios por cada 100 mil habitantes) ${ }^{56}$. Não por

55 ANUÁRIO Brasileiro de Segurança Pública. Ano 7, 2013. Disponível em: <http://www2.forumseguranca.org.br/ novo/produtos/anuario-brasileiro-de-seguranca-publica/7a-edicao >. Acesso em: 21 nov. 2013. Convém destacar que o Anuário é publicação organizada conjuntamente com a Secretaria Nacional de Segurança Pública (SENASP), sendo disponibilizada também pelo Ministério da Justiça.

56 UNITED NATIONS OFFICE ON DRUGS AND CRIME (UNODC). International homicide, count and rate per 100,000 population. Disponível em: <http://www.unodc.org/documents/data-and-analysis/statistics/Homicide/Globa_study_ on_homicide_2011_web.pdf >. Acesso em: 13 abr. 2014. 
outro motivo, notícias de linchamento de criminosos - a realização da Justiça com as próprias mãos - tornaram-se frequentes nos grandes centros urbanos brasileiros, o que, certamente, só será refreado com uma mudança de discurso político-criminal, talvez mais consentâneo com a dura realidade criminal brasileira.

\section{Referências}

ALEXY, Robert. Teoria de los derechos fundamentales. Trad. ao espanhol de Ernesto Garzón Valdés. Madri: Centro de Estudios Constitucionales, 1997.

ANUÁRIO Brasileiro de Segurança Pública. Ano 7, 2013. Disponível em: <http://www2.forumseguranca. org.br/novo/produtos/anuario-brasileiro-de-segurancapublica/7a-edicao >. Acesso em: 21 nov. 2013.

ÁVILA, Humberto. "Neoconstitucionalismo": entre a "ciência do Direito" e o "Direito da ciência". Revista Eletrônica de Direito do Estado, Salvador: Instituto Brasileiro de Direito Público, n. 17, jan./mar. 2009.

BARROSO, Luís Roberto. Fundamentos teóricos e filosóficos do novo Direito Constitucional brasileiro (pósmodernidade, teoria crítica e pós-positivismo). Revista Diálogo Jurídico, Salvador, ano 1, v. 1, n. 6, set. 2006.

BARROSO, Luís Roberto. Judicialização, ativismo judicial e legitimidade democrática. Disponível em: <www.oab. org.br/editora/revista/users/revista/12350666701742 18181901.pdf>. Acesso em: 19 fev. 2014.

BARROSO, Luís Roberto. Neoconstitucionalismo e constitucionalização do Direito (o triunfo tardio do Direito Constitucional no Brasil). Revista de Direito Constitucional e Internacional. Doutrinas Essenciais de Direito Constitucional. v. 1, maio 2011.

BRASIL. Lei 4.657/42. Disponível em: <http://www. planalto.gov.br/ccivil_03/decreto-lei/Del4657.htm $>$. Acesso em: 18 mar. 2014.

BRASIL. Superior Tribunal de Justiça. HC 72726. Disponível em: <http://stj.jusbrasil.com.br/ jurisprudencia/6275/habeas-corpus-hc-72726>. Acesso em: 10 abr. 2014.

BRASIL. Supremo Tribunal Federal. HC 95.009-4/SP. Rel. Min. Eros Grau. Disponível em: <http://www.stf.jus.br/ arquivo/cms/noticiaNoticiaStf/anexo/hc95009EG.pdf $>$. Acesso em: 08 abr. 2014.

CORREIA, Eduardo. Direito criminal. Coimbra: Livraria Almedina, 1996. v. 1.
COUTINHO, Felipe. Juiz considera maconha 'recreativa' e absolve traficante. Disponível em: <http://www1.folha. uol.com.br/cotidiano/2014/01/1404517-juiz-consideramaconha-recreativa-e-absolve-traficante-confesso. shtml>. Acesso em: 16 mar. 2014.

JUÍZES PARA A DEMOCRACIA. Decisões: prisão em flagrante. Disponível em: <http://www.ajd.org.br/ decisoes_ver.php?idConteudo=29>. Acesso em: 28 nov. 2013.

DIAS, Jorge de Figueiredo. Direito penal: parte geral. 2.ed. portuguesa. São Paulo: Revista dos Tribunais; Coimbra: Coimbra Editora, 2007. T. 1.

ESTATUTO da AJD. Disponível em: <http://ajd.org.br/ quem_somos_estatuto.php>. Acesso em: 6 abr. 2014 .

FRANCO, Alberto Silva. Do princípio da intervenção mínima ao princípio da máxima intervenção. Revista Portuguesa de Ciência Criminal, v. 2, p. 182-183, abr./jun. 1996.

HAURIOU, André. Droit Constitutionnel et institutions poliques. 3.ed. Paris: Éditions Montchrestian, 1968.

HESSE, Konrad. Escritos de derecho constitucional. 2. ed. Seleção, tradução e introdução de Pedro Cruz Villalón. Madri: Centro de Estudios Constitucionales, 1992.

KARAM, Maria Lúcia. Drogas e redução de danos. Revista Brasileira de Ciências Criminais, São Paulo, n. 64, p. 128-144, jan./fev. 2007.

KELSEN, Hans. Teoria geral do direito e do Estado. Tradução de Luís Carlos Borges. São Paulo: M. Fontes, 2005.

LIFANTE VIDAL, Isabel. Dos conceptos de discrecionalidad jurídica. Doxa. Cuadernos de Filosofía del Derecho, n. 25, p. 413-419, 2002.

MANIFESTO de repúdio às propostas de tipificação do crime de Terrorismo. Disponível em: <http://ajd.org.br/ documentos_ver.php?idConteudo=140>. Acesso em: 29 nov. 2013.

MARQUES, Luiz Guilherme. Boca da Lei. Disponível em: $<$ http://www.amb.com.br/?secao=artigo_detalhe\&art_ id=105>. Acesso em: 10 mar. 2014.

NEVES, A. Castanheira. O problema da discricionariedade. In: NEVES, A. Castanheira. Digesta: escritos acerca do Direito, do pensamento jurídico, da sua metodologia e outros. Coimbra: Coimbra Editora, 1995. p. 531-596. v. 1

NOVAIS, Jorge Reis. Direitos fundamentais: trunfos contra a maioria. Coimbra: Coimbra Editora, 2006. 
RAMOS, Carlos Henrique. Mutação constitucional. Constituição e identidade constitucional evolutiva. Curitiba: Juruá, 2013.

ROSA, Alexandre Morais da. Garantismo jurídico e controle de constitucionalidade material: aportes hermenêuticos. 2. ed. Rio de Janeiro: Lumen Juris. 2011.

SABBÁ GUIMARÃES, Isaac. Compreensão da vontade do Direito: um problema da filosofia da linguagem. MPMG Jurídico, v. 20, p. 16-18, 2010.

SABBÁ GUIMARÃES, Isaac. Dogmática penal e poder punitivo: novos rumos e redefinições. 2. ed. rev. e atual. Curitiba: Juruá, 2001.

SABBÁ GUIMARÃES, Isaac. Lei antidrogas comentada. 6. ed. rev. atual. e ampl. Curitiba: Juruá, 2013.

SOUZA, Marcelo Ferreira de. Segurança pública e prisão preventiva no Estado Democrático de Direito. Rio de Janeiro: Lumen Júris, 2008.

STRECK, Lênio. O ativismo judicial existe oué imaginação de alguns? Disponível em: <http://www.conjur.com. br/2013-jun-13/senso-incomum-ativismo-existe-ouimaginação-alguns>. Acesso em: 19 fev. 2014.

UNITED NATIONS OFFICE ON DRUGS AND CRIME (UNODC). International homicide, count and rate per 100,000 population. Disponível em: <http://www.unodc. org/documents/data-and-analysis/statistics/Homicide/ Globa_study_on_homicide_2011_web.pdf $>$. Acesso em: 13 abr. 2014.

WITTGENSTEIN, Ludwig. Tratado lógico-filosófico: investigações filosóficas. Lisboa: Calouste Gulbenkian, 2002. 